\title{
Daniel Wiesner, Taneční divadlo aneb vyprávění o Macbethovi,
}

Praha, Nakladatelství AMU, 2016, 159 stran, ISBN 978-80-7331-411-8.

\section{Miriam Hasíková}

Pokud výročí Williama Shakespeara v roce 2016 někomu uniklo, bylo to zřejmě kvưli notorické „všudypřítomnosti“ jeho díla - proto se také o aktuálnosti a nadčasovosti Shakespearova odkazu netřeba dlouze rozepisovat. Čtyřsetleté výročí úmrtí „největšího dramatika“ se na celém světě slavilo pořádáním konferencí, inscenacemi jeho děl a také jejich novými adaptacemi, př́padně vydáváním knih. $\mathrm{V}$ českém kontextu $\mathrm{k}$ tomuto jubileu přispěla publikace choreografa Daniela Wiesnera.

Knihu autor věnoval původním aktérům a tvůrcům baletu Macbeth (premiéra 6. prosince 1984), inscenaci, která se stala „nezapomenutelnou“ z několika důvodů: jednak se jí oslavilo sté výročí existence Národního divadla, jednak šlo o vůbec první balet uvedený na Nové scéně Národního divadla. Wiesnerovým cílem bylo detailně popsat vlastní práci na této inscenaci a zachytit hlavní umělecký záměr, tedy - jak i titul knihy napovídá - koncept „tanečního divadla“. Autor čtenáře zavedl „za oponu“ a seznámil jej se vznikem baletu od úplného počátku, až po úspěšnou premiéru; představil veškeré své inspirační zdroje, stejně jako celý tým tvůrců - skladatele (Václav Riedelbauch), režiséra (Antonín Moskalyk), kostyméra (Josef Jelínek) a samozřejmě baletní soubor (v dané době pod vedením Jiřího Němečka) a sólisty Národního divadla (Vlastimil Harapes a Miroslava Pešíková,Jan Kadlec a Michaela Černá, Nelly Danko a Luboš Hajn). Ačkoli autor v úvodu ohlásil, že se nejedná o dějiny tance, nýbrž o detailní popis studia jednoho konkrétního kusu, kniha mohla alespoň v obrysech obsahovat širši kontext, př́ípadně další srovnání s podobnými díly; např́klad olomoucká inscenace stejnojmenného baletu Kirilla Vladimiroviče Molčanova v choreografii Roberta Balogha uvedená v roce 2009 prrímo vybízí ke komparaci nebo alespoň ke zmínce a stručné reflexi. Je rovněž škoda, že se autor déle nepozastavil u fenoménu soutěží nových celovečerních baletů a že se pouze letmo zmínil o původní verzi vítězného, odvážně koncipovaného libreta Václava Riedlbaucha Hra s Macbethem, aneb Zpráva o třeštèni pana Krause, úřednika, kterou tvi̊rci sice 
zavrhli, ale která by z dnešního pohledu mohla představovat zajímavou ukázku progresivních uměleckých koncepcí z počátku osmdesátých let.

Velmi podnětné bylo zveřejnění Wiesnerových studijních materiáli̊, zejména různé české př̀klady Macbetha opatřené poznámkami a postřehy (s. 31, s. 33), nebo zásadní vlivy konzultací s Martinem Hilským a filmových adaptací na finální podobu baletu. Autor výborně charakterizoval problematiku baletní adaptace a věnoval jí v kapitolách Práce na nové koncepci Macbetha s režisérem Antoninem Moskalykem a Nové dramaturgické členèni Macbetha značný prostor. $\mathrm{Na}$ řadě příkladů ilustroval, v čem umění baletní adaptace spočívá, jakých úprav bývá tř̀eba a jaké úpravy byly realizovány v príípadě Macbetha: kromě předpokládané značné redukce postav popisoval zařazení pohádkově-fantaskních a tzv. atmosférotvorných prvků do inscenace (jako například „oživení blat“, s. 53).

Pro divadelních poměrů neznalého čtenáře je zde relativně obsáhlé uvedení do tehdejšího každodenního divadelně-baletního provozu. Autor zejména zdůrazňoval omezené časové možnosti baletního souboru při nácviku inscenace během plné divadelní sezóny a důležitost jednotlivých aktérů, kooperace choreografa, režiséra, kostyméra atd. Rovněž srovnával výkony, osobitou interpretaci a dramatickou akci jednotlivých tanečníků a zvláště pak tř́ párů sólistů, ztvárňujících Macbetha a Lady Macbeth, což bylo bezesporu podnětné nejen pro profesionály z baletního prostředí, ale i pro běžné čtenáře Shekaspearovy tragédie.

Za nejpozoruhodnější složku knihy považuji velké množství ilustrací, plakátů a fotografií at' už ze zkoušek, ze samotných inscenací či z konzultací mezi jednotlivými aktéry, jelikož předložený text výborně ilustrují. Mezi zvlášt pưsobivý materiál rozhodně patři bohaté spektrum kostýmních nákresů Josefa Jelínka, nebot právě kostýmy jsou pro čtenáře jedním z prvků vedoucích k pochopení unikátního charakteru celé inscenace; nicméně i další archivní dokumenty jako dopis Václava Riedelbaucha Danielu Wiesnerovi (s. 141), choreografické, technické a světelné scénáře (s. 55-59), fotografie z premiéry (s. 142), fotografie tanečníků (u fotografií na stranách 67 a 68 je zaměněn popisek, což je ale detail) mají velkou výpovědní hodnotu. Na titulní straně knihy je černobílá fotografie (všechny fotografie z inscenací jsou černobílé) Vlastimila Harapese jako Macbetha v klíčovém momentu celého dramatu, tedy přesně ve chvíli, kdy bere do rukou dýku. Toto expresivní gesto „září na černém pozadí spolu s jasně červeným nápisem „taneční divadlo“ - obě barvy symbolicky korespondují s obsahem ztvárňovaného dramatu.

Jádrem textu, zabírající téměř polovinu celé knihy (68 stran), je kapitola Fiktivni predstaveni Macbeth, která se skládá ze zevrubného popisu představení složeného z jedenácti obrazů ve třech dějstvích. V této sekci hraje zvláště významnou roli obrazový materiál, který v kombinaci s textem nejlépe demonstruje Wiesnerovu vizi „tanečního divadla“ jako souhry všech dramatických elementů 
inscenace: doplňující se úlohy kostýmů, hereckého výrazu, scény, děje a choreografie jsou zde zachyceny jasně a výstižně. Vzhledem k tomu, že autor není muzikolog, nelze mu zazlívat, že v textu zcela chyběl popis hudební složky (bylo pouze uvedeno, že skladatel celé dílo kompletně přepsal, avšak o samotné hudbě baletu není zmínka), která je zajisté nedílnou součástí popisovaného konceptu. Za kapitolou Fiktivní návštè̃va predstaveni Macbeth následovala kapitola Inscenace očima kritiky, která ocitovala kritiku madarského autora Lászla G. Szabó uveřejněnou v roce $1985 \mathrm{v}$ odborném tanečním časopise. Víceméně šlo o převyprávění již řečeného $v$ předešlé kapitole, aniž by se čtenář dověděl o jakýchkoli kritických reakcích, zahraničních či českých. V závěru knihy však autor uvedl soupis článků a recenzí týkajících se inscenace, čímž případným budoucím badatelům práci usnadnil.

Patrně nejzajímavější část knihy je obsažena v jedné ze závěrečných kapitol Život inscenace, která zveřejnila autorovy poznámky a připomínky vytvořené v letech následujících po premiéře. Uvedl své komentáře zaměřující se na detaily jednotlivých interpretací, $v$ nichž konkrétně demonstroval svou představu o inscenaci. Např́klad reflexe výkonu Bohumíra Nekuta v roli Macduffa: „Na konci prvního jednání nesmí pospíchat ze scény. Naopak, vidí falešné předstírání smutku obou protagonistů, odcházejících za smutečním průvodem, který nese zavražděného krále Duncana. Dlouze se za ním dívá - uvědomuje si souvislosti, doutná v něm podezření a zraje pomsta. V̌̌dyt je to on, který nakonec Macbetha v souboji zabije!“" (s. 143) Tyto reflexe, nejenže nejlépe charakterizují stěžejní ideu celého spisu, totiž co je „taneční divadlo“ a jak vzniká, ale rovněž se domnívám, že mohou posloužit jako inspirace pro jiné jevištní tvưrce.

Pokud jde o formální stránku textu a stylistiku, kniha neobsahuje žádné chyby ani překlepy, autor při popisu tance využíval širokou paletu termínů technických i poetických, prričemž myslel na čtenářův komfort a nezabíhal do francouzské baletní terminologie. I grafická úprava a typografie knihy byly provedeny velmi vhodně, obojí zohledňovalo požadavek čtenářovy bezproblémové orientace $\mathrm{v}$ textu. Přestože autor již v úvodu avizoval, že knihu věnoval primárně svým kolegům, myslím, že by se publikace tohoto typu zcela jistě obešla bez výrazů jako „to by však bylo, aby česká hlavička něco nevymyslela“ (s. 52) či poznámek týkajících se osudu sborových tanečnic, které „se dodnes schází, aby si u vínka zavzpomínaly“ (s. 53).

Daniel Wiesner tuto knihu pojal jako popis své práce choreografa na baletním opusu a vytvořil tak sondu do vzniku a vývoje inscenace, na níž názorně představil svou představu o „tanečním divadle“, inspirativní umělecké koncepci určené pro další jevištní tvůrce. Interdisciplinární rozměr „tanečního divadla“ (stejně jako Shakespearova díla vůbec) však umožňuje zapojení mnoha jiných oborů, proto 
může být spis př́nosný i pro dramatiky, anglisty, literární vědce, muzikology či historiky. Závěrem nutno podotknout, že verbalizovat taneční akci není nijak snadné, proto patři autorovi velké uznání i dík za tento plnohodnotný př́spěvek nejen k oslavě Shakespearova jubilea, ale i k relativně skromné české baletní literatuře. Vydavatelství Akademie múzických umění již v minulosti publikovalo rozmanité spisy zabývající se baletem, přejme si tedy, aby se řady české baletní literatury dále úspěšně rozšiřovaly. 